\title{
Egy Petzval-vitáról
}

\author{
ALBERTINI BÉLA \\ Kaposvári Egyetem Művészeti Kar, H-1077 Budapest, Dohány u. 46., \\ e-mail: bela.albertini@gmail.com
}

\begin{abstract}
Albertini, B.: About Petzval Debate.
Abstract: In 1920, Eduard Kuchinka from Vienna started a debate with Viktor Teißler from Prague in the „Photographische Korrespondenz". The latter stated in London's Penrose's Annual that given his place of birth, Josef Petzval (Petzval József 1807-1891), the famous lens constructor was of "Czechoslovakian" descent. Kuchinka showed that Szepesbéla, Petzval's place of birth became part of Czechoslovakia only after the World War. The author from Vienna compensated the Czechoslovakian bias with his own German bias: according to him, Petzval was of German descent. The true facts are: József Petzval was born on the territory of the Austro-Hungarian Empire, with his paternal side being Czech (maybe Moravian), his spindle side being German. Any such claim of appropriation is unscholarly.
\end{abstract}

Keywords: lens constructor, Szepesbéla, origin in regard of birthplace, ethnic origin, political impulse, national prejudice, peace treaty, citizen

1920 novemberében egy olyan cikk jelent meg a nagy múltú, 1864 óta funkcionáló osztrák Photographische Korrespondenz hasábjain, ${ }^{1}$ amely figyelmet érdemel mind a korai magyar fotótörténet, mind az akkori hazai politikai, társadalomtörténeti viszonyok szempontjából.

Ez az írás csak E. K. szignóval volt ellátva, a korabeli ausztriai szakirodalomban tallózva azonban jól látható, hogy a név kezdőbetűk mögött Eduard Kuchinka állt. - Kuchinka (1878-1930) a hírneves bécsi Graphische Lehr- und Versuchsanstaltban szerzett fotográfusi szakképesítést, 1898-tól az intézmény „szertárőre” lett (az objektív- és fényképezőgép-gyűjtemény gazdája volt), részt vett továbbá a Photographische Korrespondenz szerkesztőségi munkájában. Több önálló szakkönyv szerzője, fotográfiai évkönyvek társszerkesztője és számos fotótechnikai cikk írója volt. ${ }^{2}$ Kuchinka elhunytáról megemlékezett az 1922 óta funkcionáló svájci Camera című fotográfiai folyóirat is. ${ }^{3}$

Az ausztriai szerző cikkében a cseh dr. Viktor Teißlernek (1883-1962) a londoni Penrose's Annualban közreadott egyik állítását vitatta. ${ }^{4}$ - A matematika-fizika szakot végzett prágai cikkíró 1910-ben doktorált, inkriminált cikkének megjelenésekor tanárként működött a

1 E. K[uchinka] 1920: Prof. Dr. Josef Petzval Nationalität. Photographische Korrespondenz 57: 290-291.

2 Eduard Kuchinka 1930: Photographische Korrespondenz 66: 222.

3 Eduard Kuchinka 1930: Camera 9: 144

4 V. Teissler 1920: Three Famous Pioneers in Photography. Penrose's Annual Process Yearbook 22: 81-84. csehszlovák fövárosban. ${ }^{5} \mathrm{Az}$ 1920-as angol orgánum, amelyben a Three famous pioneers in photography címü cikk fölött a szerző neve eredetileg Teissler írásmóddal szerepelt, mai ismereteim szerint magyarországi könyvtárakban nem lelhető fel. - Az 1895-töl kiadott periodikumból az 1906-os kiadvány megvan a Magyar Képzőművészeti Egyetem könyvtárában, az 1929-es az Országos Széchényi Könyvtárban, az 1931-es pedig a Müszaki Egyetem könyvtárában, ez a magyar fotókultúra nézőpontjából fontos kötet azonban egyik említett helyen sincs meg (1. és 2. ábra).

Teissler cikke bevezetőjében arról szólt, hogy amikor a "cseh-szlovákok” felszabadultak az osztrák fennhatóság alól, ő kérte a szerkesztőt, hogy ezen a fórumon felhívhassa a figyelmet "nemzete néhány tagjára”, akiknek munkássága világszínvonalon is számottevő. ${ }^{6}$ A prágai szakíró tehát bevallottan politikai indíttatású írást hozott nyilvánosságra. Önmagában véve ettől cikke még megfelelhetett volna a tudományos hitelesség követelményeinek. Azonban mint az látható lesz, a frissen létrejött csehszlovák állam polgárának látásmódját a túlbuzgó nemzettudat eltorzította, s a szerzőt történetietlen állításokra ragadtatta.

Kuchinka felidézte, hogy a Teissler (Kuchinkánál: Teißler) által a fényképezés egyik úttörőjeként megnevezett kiemelkedő tudós, a portréobjektív megtervezője [szó szerint: kiszámítója, amely kifejezés helyénvaló, hiszen a tervező egykor valóban kiszámolta az akkor forradalmi jelentőségű objektív mutatóit], „Prof. Dr. Ing. Josef Petzval” a cseh szerző szerint "csehszlovák" származású volt (3. ábra). A kritikusi szerepre vállalkozó bécsi szakember - írása címének megfelelöen - a továbbiakban alapvetően csak a Petzvalra vonatkozó Teißler-kitételekkel foglalkozott, bár azt is szóvá tette, hogy a harmadik úttörőként felsorolt Karl Klič, a heliogravür feltalálója máig [azaz 1920-ig] Bécsben él, és következetesen Klitsch-ként írja a nevét. - Megjegyzést érdemel, hogy Karel Klič a csehországi Hostinnéban született 1841-ben, Prágában járt képzőművészeti akadémiára, a fényképezést is hazájában tanulta meg, mert apja fényképészként dolgozott Brnóban. Klič (későbbi írásmód szerint: Klitsch, Klietsch) 1867-töl Bécsben, Pesten majd Londonban müködött, 1897-töl halálig, 1926-ig Bécsben élt. ${ }^{7}$

5 Teissler Viktor 1994: Slovenský biografický slovník, VI. - Martin, Matica Slovenská, p. 36.

6 V. Teissler 1920: i. m. 81

7 R. Urban 1926: Památce akad. malíře a grafika Karla Kliče. Fotografický obzor, 34: [161]-164. 


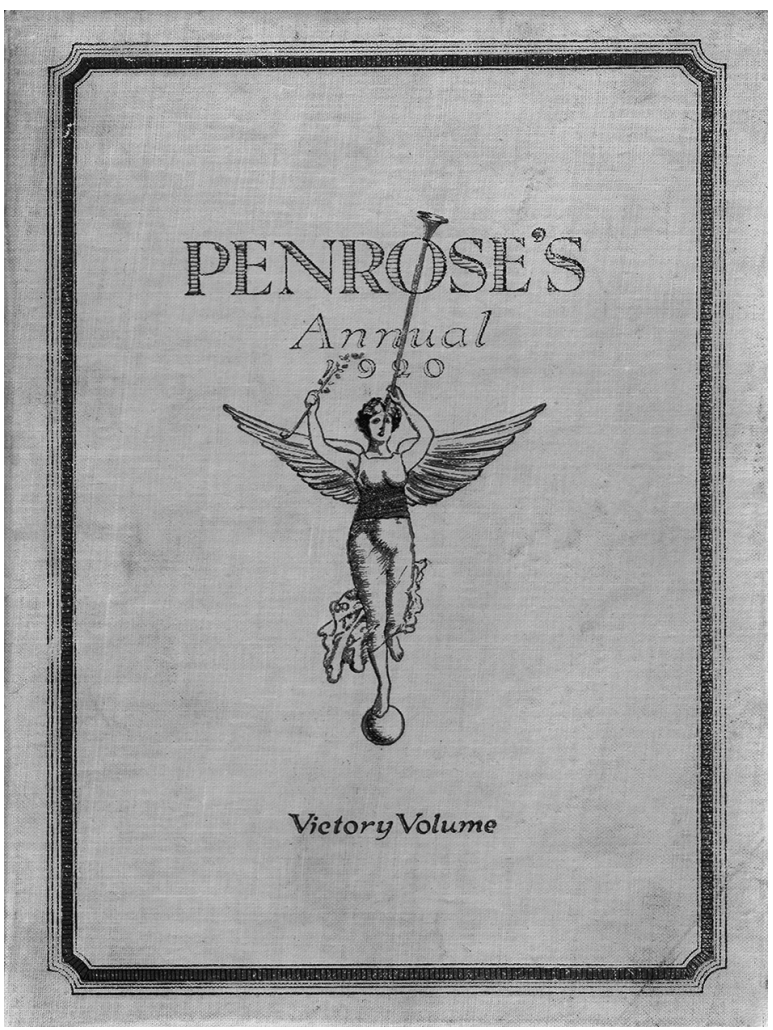

1. ábra. Penrose’s Annual 1920 - borító
A Korrespondenz cikkírója szerint Teißlernek a származást bizonyítani szándékozó állítása - miszerint Petzval egy kelet-szlovákiai tartományban született volna - hamis. Kuchinka úgy vélekedett: ez az állítás alkalmas lehet arra, hogy Petval származásáról külföldön is félrevezető képet fessen, ezért törekszik ő a továbbiakban helyesbítésre. Érvelésében egy dr. Erményi által írt Petzval életrajzból indult ki. Ez első ízben 1902-ben, majd 1903-ban jelent meg a fotókönyvei révén már akkor hírneves Knappnál Halleban. ${ }^{8}$ - A Bécsben élő, s a Ferdinánd császár Vasútnál működő mérnök, Erményi Lajos (1843-1929) „...Petzval földije, majd tanítványa és később barátja..." által írt életrajz valamivel később magyarul is megjelent. ${ }^{10}$

8 L. Erményi 1902:, 1903: JosefPetzval's Leben und wissenschaftliche Verdienste. - Halle, Knapp Verlag. Megemlítendő, hogy Seress János Petzval életrajzában - Petzval József (1807-1891) a fényképező optika magyar származású feltalálójának mérnöki professzori és feltalálói müködése, Budapest, Tankönyvkiadó, 1954. - Petzval munkásságával kapcsolatban Erményitől több német nyelvű írás bibliográfiai adatai is olvashatók - Seress p. 54.

9 Seress J. 1954: Petzval József, i. m. p. 4

10 Erményi L. 1906: Petzval József élete és érdemei. - Budapest, Franklin Nyomda. - Lehet, hogy fotótechnika-történész kollégánk egykori panasza, miszerint nehéz hozzájutni a Petzval életrajz magyar nyelvű változatához, - Fejér Z. (2004): Európai kalandozások, 8. rész: Cselovek sz fotoapparatom (1). Fotóművészet 47: 1-2. 1. - hatékony volt, mert a Barnaföldi G. Archívum 2007-ben reprintben kiadta Erményi kis könyvét, így most sokak számára könnyen elérhető.

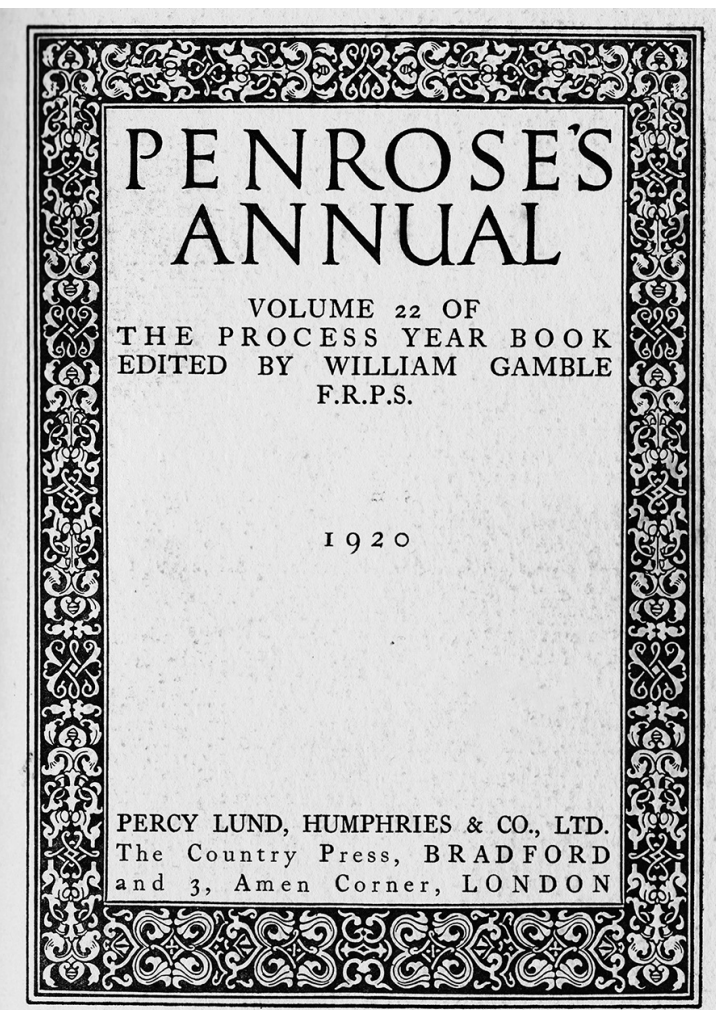

2. ábra. Penrose’s Annual 1920 - címoldal

Kuchinka kézenfekvő módon idézte Erményitől, hogy Petzval születési helye egy Szepes megyei kisváros, „Szepes-Béla” volt, ez a terület pedig Petzval születésekor $s$ egészen a világháború végéig a Magyar Királysághoz tartozott. Az, hogy ezt a megyét a saint-germaine-i béke után az újonnan alakult Csehszlovákia kebelezte be (eredetiben: „einverleibt wurde"), még nem bizonyítja Teissler igényét, szögezte le Kuchinka. ${ }^{11}$ Bár ebben nyilvánvalóan igaza volt, a felvetés jelzi, hogy őt is politikai motiváció indította kritikára. Emberileg érthető, hogy Kuchinka számára a Saint-Germaine-ben 1919. szeptember 10-én Ausztriával kötött békeszerződés volt fájdalmas, ugyanakkor meg kell jegyezni, hogy Szepes vármegye - mint az első világháború előtti Magyar Királyság része - nem a saint-germain-i, hanem a trianoni békeszerződés következményeként került Csehszlovákiához. ${ }^{12}$

Történelmi tény, hogy Petzval József az egykori Magyar Királyság területén született. - Azt nem lehet mondani, hogy magyar állampolgárként, mert az állampolgárság, mint jogi kategória a polgárosodás folyamatában jött létre, s Magyarországon csak később rendelkezett róla elöször jogszabály. (1879: L. tcz. A magyar állampolgárság megszerzéséről és elvesztéséről. ${ }^{13}$ ) Ezen a ponton

11 E. K[uchinka] 1920: i. m. 290.

12 1921: XXXIII. tc. A Trianonban kötött békeszerződés - 1921: In: Magyar törvénytár, 1921. évi törvénycikkek. Budapest, Franklin, p. 210-212.

13 Magyar törvénytár 1886: 1879-1880. évi törvényczikkek, Budapest, Franklin Társulat., p. 221. 


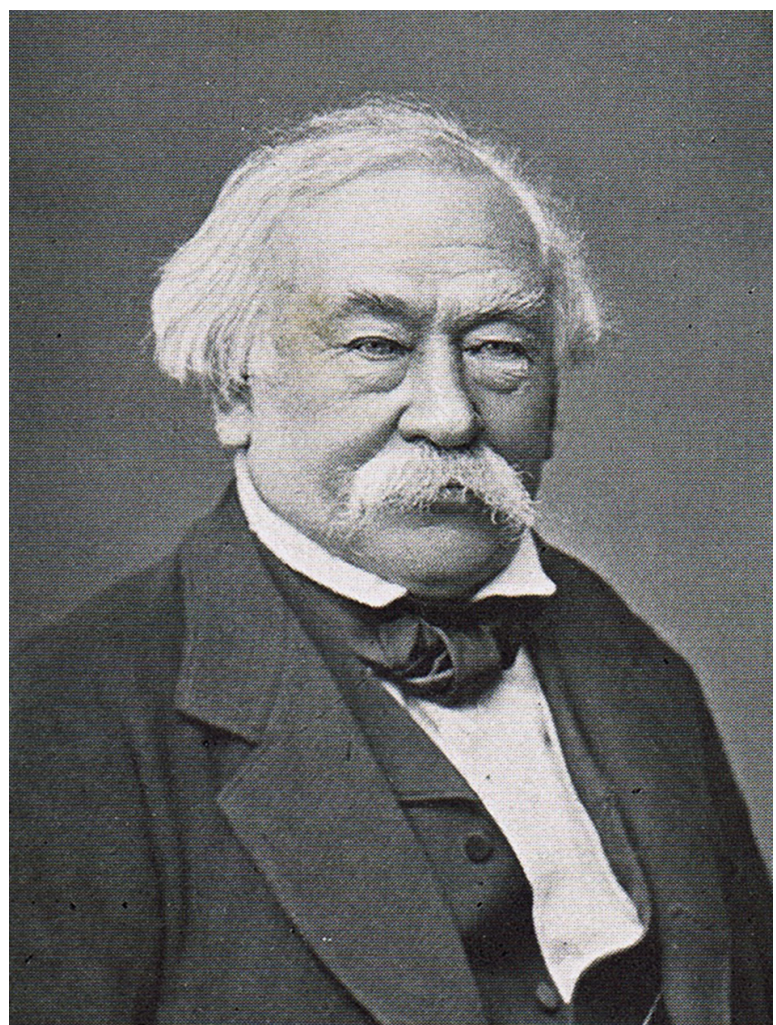

3. ábra. Petzval József portréja - forrás: Penrose's Annual 1920. 84. p. utáni mümelléklet

indokolt felhívni a figyelmet arra, hogy az állampolgári hovátartozás kérdése, - mint erre a jogi szakirodalom is int - nem mosható össze az etnikai származás problémájával. ${ }^{14} \mathrm{Az}$ erre vonatkozó különbségtétel a továbbiakban is fontos támpontot jelent ebben az eszmefuttatásban.

Kuchinka replikája a Korrespondenzben úgy folytatódott, hogy a "cipszer megye" (Szepes vármegyéről van szó) lakosai német nemzetiségúek voltak, s Petzval apja német tanító volt, aki később Késmárkon és Lőcsén, ugyancsak a Szepességben müködött. ${ }^{15}$ Ő azonban nem Szepesbéláról származott. Petzval József apja, „...Petzval Ján Fridrich, eredeti nevén Pecival Jan Křitel [volt], aki 1775. július 4-én született a loděnicei tanító, Pecival František és Rosalie nevű felesége fiaként.”16 (A Pecivál egy „beszélő név”, magyarul otthonülőt, semmittevőt, finomabban lustát jelent.) Loděnice morvaországi település Znojmo közelében. Idevágó részletes genealógiai források híján nem lenne célszerü belemenni a cseh vagy morva kérdés taglalásába, amely máig szenzitív probléma Csehországban, ${ }^{17}$ annyi mindenesetre leszögezhető, hogy Petzval József apai ágon szláv származású volt.

14 Hargitai József 2005: Jogi fogalomtár, Budapest, Magyar Hivatalos Közlönykiadó, p. 83

15 E. K[uchnika] 1920: Prof. Dr. Josef Petzvals Nationalität - i. m. 290.

16 Konkoly P. 1995: Petzval életének első húsz éve a Szepességben. - Fizikai Szemle 45: 16.

17 Hamberger J. 2000: Morva identitás, morva autonómia. In: Szlovákokról és csehekről magyar szemmel: tanulmányok, elemzések, Pozsony, Kalligram, pp. [53]-74.
Ugyanez a szlovákiai forrás közli, hogy Ján Fridrich Petzval, aki 1799-ben került tanítónak Szepesbélára, 1801-ben feleségül vette Kreutzman Zsuzsannát, akivel 1800-ban történt eljegyzésük óta élettársi kapcsolatban élt, s már volt egy házasságon kívüli gyermekük, aki rövidesen meghalt. ${ }^{18} \mathrm{Ez}$ a forrás valamilyen okból nem tért ki a feleség személyes adataira, azonban egy másik - jubileumi alkalomból készült - magyarországi írás közli, hogy ő egy cipszer szepesbélai tanító lánya volt. ${ }^{19}$ - Ehhez a Kreutzman név elég beszédes adalék.

Egyértelmű tehát, hogy a Petzval-Kreutzman házasságból a Magyar Királyság területén született Petzval József etnikai szempontból cseh (morva?) és német felmenőktől származott.

Kuchinka a továbbiakban felidézte, hogy Petzval „a Budapesti Egyetemre járt”; „Budapesten” volt állami alkalmazásban, majd a „Budapesti Egyetemen” volt a felső matematika professzora - ami tartalmilag mind helytálló, leszámítva azt, hogy mint az közismert, Budapestről csak az 1873-ban végbement városegyesítés után lehet szólni. ( $E$ tekintetben Kuchnika és Teissler közös platformon voltak: a vitát kiváltó cikkében az 1873 előtti időkról szólva a cseh szerző is következetesen Budapestről írt. Ami Petzval mérnöki tanulmányait illeti, mind Teissler, mind Kuchinka közleményét annyiban kell pontosítani, hogy a számára képzettséget nyújott intézmény a Pázmány Péter által alapított, majd 1777-ben Budára helyezett Tudományegyetem keretei között müködött. ${ }^{20}$

Figyelmet érdemel, hogy bár Kuchinka tételesen nem használta a „osztrák” jelzőt, cikkében keveredett a német és az osztrák fogalom. A továbbiakban ugyanis arról értekezett, hogy akik az Osztrák-Magyar Monarchiában állami szolgálatba - így egyetemi állásba - kerültek, kiléptek „korábbi hazájuk kötelékéből”, így tett Petzval József is, aki húszévi bécsi tartózkodás után elnyerte az állampolgársági jogot (eredetiben: Heimatsrecht) - s erről Teisslernek mint az egykori Monarchia polgárának tudni kellene. ${ }^{21}$ Megjegyzést érdemel, hogy Kuchinka erről a részkérdésről írva semmilyen konkrét dokumentumra sem hivatkozott,

18 Konkoly P. 1995: u. o.

19 Rezsabek Nándor 2009: Kétszáz esztendeje született Petzval Otto. - Evangélikus Élet 74: 6. - a cikk Petzval Ottóról, Petzva József öccséről szólt, aki mérnökként müszaki és természettudományi területen vált hírnevessé.

- Megjegyzést érdemel, hogy Teißler írásának adatai megtalálhatók Seress János fentebb idézett munkájában is - Seress 59. az erre reagáló Kuchinka cikk viszont nem. Kuchinka fotográfiai íróként egyébként nem volt ismeretlen Seress számára, erre bizonyság, hogy bibliográfiájában egy későbbi, a Petzval-objektívve kapcsolatos cikkkének adatait - éppen a Photographische Korrespondenzböl - meg is adta (Seress 56.). A vitacikk bibliográfiai megidézésének hiánya Seressnél így feltehetőleg abból adódott, hogy az egyébként igen alapos irodalomkutatást végzett szerző annak idején az E. K. szignó mögött nem ismerte fel Kuchinkát. Különös, hogy Seressröl, akitöl a mai napig a legalaposabb Petzval életrajzot ismerjük, a jelen pillanatig semmi közelebbit nem tudunk. Ha azonos lenne az 1920-ban Sátoraljaújhelyen született Seress János egykori közszereplővel, az a magyar fotótörténetírás története számára újabb kérdéseket indukálna.

20 Németh József 1999: A technika és mérnőkség magyarország története (Mérnökszerepek és ipartörténeti korszakváltások), Budapest, Müegyetemi Kiadó, p. 82.

21 Kuchinka 1920: i. m. 291 


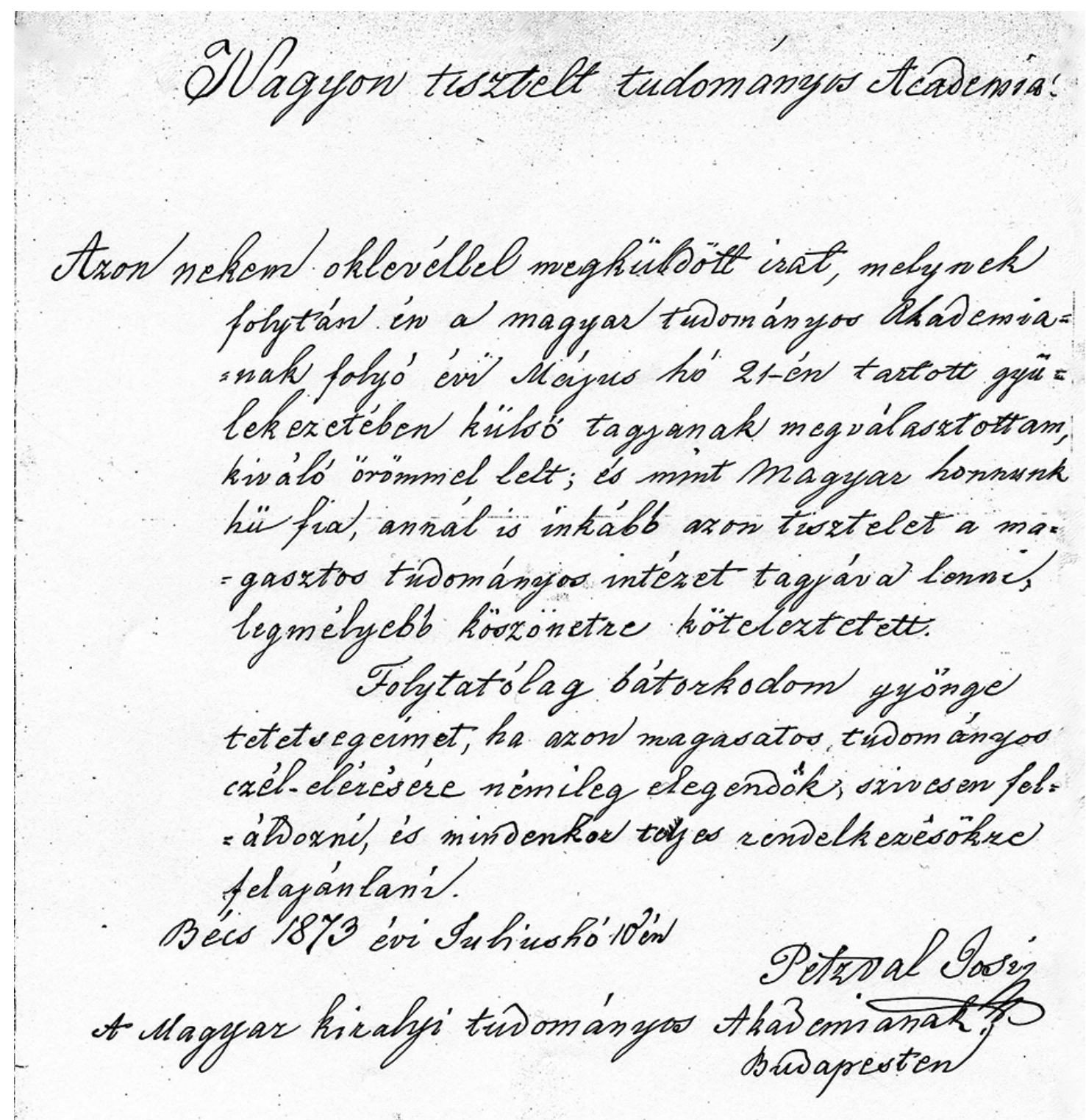

4. ábra. Petzval József levele a Magyar Tudományos Akadémiának - 1873. július 10.

de mint az látható, voltaképpen osztrák állampolgárnak minősítette Petzvalt.

A bécsi író a továbbiakban Petzval nyelvtudásáról szólva Erményi visszaemlékezését némi csúsztatással interpretálta. Cikkét ugyanis így folytatta: „Wenn wir noch weiter den eingehenden biographischen Daten Dr. Erményis über Petzval, so finden wir, das Petzval die deutsche, lateinische und französische Sprache volkommen, weiniger die englische und ungarische Sprache beherrschte;..."22. A valóságban Erményi azt írta Petzvalról: „An Sprechen beherrschte er außer der deutschen ebenso vollkommen auch die lateinische und französische; aber auch in der englischen und ungarischen war er ausreichend bewahren." ${ }^{23} \mathrm{Nem}$

22 Kuchinka 1920: uo.

23 Erményi 1903: i. m. 14. kétséges, hogy a Kuchinka-szöveg „weniger [...] beherrschte" fogalmazása gyengébb magyar nyelvtudást jelent, mint az eredeti Erményi-féle szövegé „...aber auch [...] war er ausreichend bewandert." Ha Erményi állításáról szólva felidézzük azt a tényt, hogy Petzval egykor 11 évet töltött Pesten és Budán, akkor annak Kuchinkáénál reálisabb volta elég meggyőző.

A folytatásban Kuchinka érvelése alátámasztásához Eder professzornak, mint Petzval egyik legjelentősebb kortársának és személyes ismerősének írását idézte meg. Josef Maria Eder (1855-1944) kémikus, fotográfia tanár, fotótörténész, az osztrák fotókultúra egyik legtekintélyesebb képviselője több kiadást is megért fotótörténetének egyik lábjegyzetében valóban azt írta, hogy Petzval hangsúlyosan kijelentette szá- 
mára: ő német szülőktől származik. ${ }^{24}$ Nincs ok Eder kijelentésének hitelességét kétségbe vonni, bár meg kell jegyezni, hogy az ő fotótörténetének megjelenései idején Petzval már nem élt.

Ugyanakkor Eder visszaemlékezése mellé oda lehet tenni egy másik - a mai napig ténylegesen létező - dokumentumot, amelyben Petzval „magyar honunk [eredetiben: honnunk - A. B.] hű fiá"-nak nevezte magát. (4. ábra) Ez egy a Magyar Tudományos Akadémiához intézett, 1873. július 10-én kelt köszönőlevél, amely abból az alkalomból keletkezett, hogy az Akadémia Petzvalt külső tagjává válaszotta. ${ }^{25}$ Mai terminológiával élve azt mondhatjuk, hogy Petzval itt magyarnak minősítette magát. Nincs-e ellentmondás ezen állítás és az Edernek (állítólag) tett nyilatkozat között? Ismét mai jogi szabályozást véve figyelembe - ami természetesen visszavetítés lenne, s mint ilyen, tudományos közelítésben nem járható út - de tartalmilag végiggondolható. $A$ válasz: nincs ellentmodás. A jelenleg hatályos egyik magyar törvényben van egy passzus, amely kimondja: „A nemzeti és etnikai önazonossághoz való jog és ilyen kisebbséghez való tartozás vállalása és kinyilvánítása nem zárja ki a kettős vagy többes kötődés elismerését." ${ }^{26}$ - Ez az értelmezés nem zárná/zárja ki a szláv (cseh, esetleg morva, alkalmasint szlovák) kötődést sem...

Mit lehet ehhez ma hozzátenni? Ahhoz ugyanis, hogy mint azt fentebb láthattuk, Petzval József a Magyar Királyság területén született cseh (vagy morva) és német felmenőkkel rendelkező szülők családjában, továbbá hogy a neki világhírt hozó fényképező objektív megtervezésekor tartósan Bécsben müködő professzor volt. Ha megpróbálunk kívül maradni bármilyen irányú nacionalista elfogultságon, akkor azt kell mondani, hogy Petzval matematika és fizika ország állampolgára volt. Lévén, hogy ilyen ország az atlaszon nem található, ez az állítás nyilvánvalóan metafora - bár realista, és tudományos igényű. Tényszerűen

24 Josef Maria Eder 1905: Geschichte der Photographie. Dritte ganz umgearbeitete und vermehrte Auflage, Halle, Verlag von Wilhelm Knapp, [221.] Eredetiben: "Zu wiederholtem Male erwähnte ich daß mir $\mathrm{P}$ e $\mathrm{t} z \mathrm{z}$ a I selbst unter Betonung der Tatsache, daß er von deutschen Eltern geboren sei, [...]" - kiemelés az eredeti szövegben.

25 Magyar Tudományos Akadémia Kézirattára, RAL, 667/1873. - Ezt a levelet mai ismereteim szerint Seress János adta közre első ízben 1958-ban - J. S. Seres: Reflexion to the Petzval's Memorials, Acta Technika, 1958. p. 213.

26 Az 1993. évi LXXVII. törvény a nemzeti és etnikai kisebbségek jogairól: Törvények és rendeletek hivatalos gyüjteménye, 1993. 1. köt. II. fejezet, Egyéni kisebbségi jogok, 7. §. (2) bek. Budapest, Közlöny- és Lapkiadó Kft, 1994, p. 319 és történeti közelítésben nézve tudomásul kell venni, hogy ez a bonyolult képlet megfelel a Kárpát-medence, tágabban szemlélve Közép-Európa egykori viszonyainak. Ebből kiindulva tudni kell különbséget tenni a születési hely adottságai és az etnikai származás kérdése között, s tudomásul kell venni, hogy bonyolult alaphelyzetnek bonyolult - és semmilyen nem tudományos alapú indíték okán nem leegyszerüsíthető következmények felelnek meg.

Mit tudhatott annak idején, 1920-ban a fentebb vázolt konfliktusról a magyar fotográfus társadalom? Nagyon valószínű, hogy az idézett angol nyelvű közlemény anno nem került magyar kézbe. A riposztozó Fotografische Korrespondenz cikk viszont minden bizonnyal igen, hiszen ismert, hogy decemberben egy magyar szerző is írt oda egy kiállítás-ismertetőt; ${ }^{27}$ ez az osztrák szakmai orgánum már a háborút megelőzően is olvasott lap volt magyar szakmai körökben. Ezzel kapcsolatos kortársi reagálást ez ideig nem ismerek. Nagyon valószínü, hogy Petval József nemzetiségének a világháborút lezáró békeszerződések jegyében történő vitatása itthon csak egy volt a Trianon okozta frusztráció adalékaiból.

\section{Köszönetnyilvánítás}

A tanulmány előkészítését segítők: Árvayné dr. Kucsera Judit (Országos Müszaki Információs Központ és Könyvtár); Csuka Béla (Magyar Nemzeti Levéltár Országos Levéltára); Hushegyi Gábor (Szlovák Intézet, Budapest); Kápolnai Kázmér (Bp., VIII. kerületi Szlovák Önkormányzat); Képzőmüvészeti Egyetem Könyvtára, Budapest; Magyar Tudományos Akadémia Kézirattára, Országos Széchényi Könyvtár, Budapest; Österreichische Nationalbibliothek, Wien; Pet'ovská Flóra (Cseh Centrum, Budapest), Zsidi Vilmos (Corvinus Egyetem Levéltára)

\section{Irodalom}

BERNOLÁK K. 1991: Petzval József, a fotográfiai optika megalapítója. - Fotómúvészet 33:52-53.

DoBSZAY T. 2005: A művelődés és a műveltség polgárosodása. In: Magyarország története a 19. században. Szerk. Gergely A. Osiris Kiadó, Budapest

FEJős I. 1957: A magyar fényképezés kezdetei. - Folia Archaeologica 9: 243-255.
Holzer A. 2013: Fotografie in Österreich. Geschichte - Entwicklungen - Protagonisten 1890-1955. Metroverlag, Wien

Romsıcs I. 1999: Magyarország története a XX. században. Osiris Kiadó, Budapest

Romsıcs I. 2015: Trianon okai. In: - A múlt arcai. Történelem, emlékezet, politika. Osiris Kiadó, Budapest 329-365. 
